\title{
Chinese Urban Planning
}

Environmentalising a hyper-functionalist machine?

\section{Rémi Curien}

Translator. Will Thornely

\section{Q OpenEdition}

\section{Journals}

\section{Electronic version}

URL: http://journals.openedition.org/chinaperspectives/6528

DOI: 10.4000/chinaperspectives.6528

ISSN: 1996-4617

\section{Publisher}

Centre d'étude français sur la Chine contemporaine

\section{Printed version}

Date of publication: 1 September 2014

Number of pages: 23-31

ISSN: 2070-3449

\section{Electronic reference}

Rémi Curien, «Chinese Urban Planning », China Perspectives [Online], 2014/3 | 2014, Online since 01

January 2017, connection on 28 October 2019. URL : http://journals.openedition.org/

chinaperspectives/6528; DOI : 10.4000/chinaperspectives.6528 


\title{
Chinese Urban Planning
}

\section{Environmentalising a hyper-functionalist machine?}

\section{RÉMI CURIEN}

\begin{abstract}
How should the considerable discrepancy between the concepts of sustainable urban development proclaimed by the Chinese authorities and the reality on the ground be understood? This article examines the urban planning procedures that currently hold sway in China. The building of new cities is based upon a generic method of hyper-productivist and functionalist planning, reflected as a pyramid structure that extends over the whole country and is embodied by urban zoning on a vast scale. This procedure, which has been in force for nearly 30 years, is not at present one that is called into question by Chinese decision-makers, and does not take environmental principles seriously into account. Conversely, all of the reasoning upon which urban development is based remains very far removed from environmental considerations. China is continuing down the road of accelerated development behind the wheel of a growing hyper-functionalist urban machine.
\end{abstract}

KEYWORDS: urban planning, environment, sustainable development, urban planning model, functionalist urban planning, utilities networks, institutional system, SIP (Suzhou Industrial Park).

l: $n$ the three decades since the turning point in 1979 when China began to open up to the market and to the rest of the world, it has experienced double-digit growth and an unprecedented rate of urbanisation. The number of city dwellers stood at 190 million in 1979 , representing $20 \%$ of the total population; today it stands at 700 million, or $52 \%$ of the population, (1) and the number of people living in Chinese cities swells by 15 to 20 million every year. Over the course of the next 15 years, the country's cities are expected to welcome 300 million new inhabitants, (2) equalling the number of houses in the whole of Europe today; in other words, by 2030 there will be a billion urban inhabitants, and the urbanisation level will have risen to $68 \% .{ }^{(3)}$ Chinese cities have become powerful production and wealthcreation machines. This phenomenal development has enabled China to become a major world power, and has paved the way for improved living standards for its population, although major social disparities do remain. However, it has also brought increasing pressure to bear on natural environment, and has led to major environmental damage, seriously compromising the quality of living conditions in China for the medium and long term, triggering major threats to the availability and sustainability of natural resources and to the health of the country's population - and even its economy - and basically resulting in a critical situation today. ${ }^{(4)}$ Civen this context, in which the equation between accelerated development and urbanisation and protection of the environment has become an acute issue, the question of how cities are planned and built, which largely determines urban metabolism, is a strategic one that represents a major challenge to the state of the environment in China and across the world.

\section{The turning point in urban sustainability proclaimed by the Chinese authorities}

The Chinese authorities have been fully aware since 2006 of the serious nature of the environmental challenges: the first official Chinese report on the environment, conducted by SEPA/NBS, was published in 2005, and the

$11^{\text {th }}$ Five-Year Plan (2006-2010) recommended a new and more balanced development model that gives greater consideration to the environment. ${ }^{(5)}$

I am supervised in my research by Olivier Coutard (CNRS) and also work closely with Dominique Lorrain (CNRS). My PhD work is a part of the SYRACUSE ANR program (which brings together the Suez Environment Group and in particular Safege, LATTS, Sciences Po Paris and the EPA Plainede-France). I thank Olivier Coutard, Dominique Lorrain, Carlos Campos (Suez Environnement), Françoise Ged (Cité de l'architecture et du patrimoine), Zhuo Jian (Tongji University), and Taoufik Souami (UMLV) for their helpful remarks.

1. National Bureau of Statistics of China, 2013 data.

2. These numbers include tens of millions of migrants who live in "urban areas" but do not have official town- or city-dwelling status.

3. See the United Nations report, World Urbanization Prospects, The 2011 Revision, New York, 2011.

4. There is now scientific consensus concerning the environmental diagnosis of Chinese cities, which is very worrying on all fronts: scarcity and pollution of water resources, air pollution, waste management, etc. Three hundred Chinese cities experience water shortages, the situation reaching a critical level in a third of them. It is claimed that 20 of the world's 30 most polluted cities are in China. In particular see: Elizabeth C. Economy, The River Runs Black:The Environmental Challenge to China's Future, Ithaca and London, Cornell University Press, 2004; Peter Ho and Eduard B.Vermeer, China's Limits to Growth: Greening State and Society, Oxford, Victoria, Blackwell Publishing, Malden, 2006; Frédéric Obringer, "La croissance économique chinoise au péril de l'environnement: une difficile prise de conscience" (Chinese economic growth and the environment under threat: A difficult realisation), in Hérodote, No. 125, 2007, pp. 95-104; OECD, Environmental Country Reviews by the OECD:China, Paris, OECD, 2007; Emmanuel Guérin and Laurence Tubiana, "Les limites environnementales de l'émergence" (The environmental limits of development), in L'Enjeu mondial. Les pays émergents (The international challenge. Emerging countries), Paris, Presses de Sciences Po, 2008; Wu Fengshi, "Environmental Politics in China: An Issue Area in Review," Journal of Chinese Political Science, Vol. 14, No. 4, 2009, pp. 383 406; Hao Xiaodi et al., Water Infrastructure for Sustainable Communities - China and the World, IWA Publishing, 2010; Dominique Lorrain, "Gouverner Shanghai: une modernisation publique" (Governing Shanghai: Public modernisation), in Dominique Lorrain (ed), Métropoles XXL en pays émergents (XXL metropolises in emerging countries), Paris, Presses de Sciences Po, 2011

5. The factors that help explain the increasing environmental awareness of the authorities are both internal and external. Internally, increasing pressure has been brought to bear from within the country by civil society and community and scientific circles, and there are increasing concerns among the leaders of the CCP concerning social tensions brought about by environmental crises and the danger that they represent to the authority of the Party. External factors include the gradual integration of China into the entente of nations and international trade, and the lobbying carried out by international foreign players (the World Bank, OECD, consultancy businesses, task forces, etc.). In this context, the construction of a Chinese environmental political framework can be interpreted, first and foremost, to be a "defensive" or "fire-fighting" strategy by the Chinese authorities to contain criticism from the national population and the international community. However, it is also adopting an "attacking" strategy promoting the influence and embodiment of Chinese modernity, whereby environmental protection is upheld as evidence of China's advanced position on the development scale, and as the ultimate passport proving the modernity of Chinese cities to the rest of the world. 
At that time, the authorities expedited the construction of a political, institutional, and legal framework for environmental matters. As far as urban planning is concerned, new concepts, laws, programmes, and projects promoting greater consideration for the environment began to see the light of day in 2006.

Two concepts were created with a view to forming the ultimate goal of urban development in China: yongxu chengshi (similar to the Western idea of a "sustainable city") and hexie chengshi ("harmonious city," a concept favoured and backed by the central authorities at the UN-Habitat World Urban Forum organised in Nanjing in $2008{ }^{(6)}$ because they considered its focus on the idea of seeking social, environmental, and temporal balance and stability to be more deeply rooted in the Chinese way of thinking). A new urban planning law approved in 2008, the "Urban and Rural Planning Law" (chengxiang guihua fa), placed environmental questions at the heart of the aims and principles assigned to territorial planning: ${ }^{(7)}$ careful use of land, improvement of the ecological environment, promotion of the rational and sparing use of energy and natural resources, protection of land suitable for cultivation and natural resources, etc. The environmental objective now also features prominently in urban planning documents at the municipal level, zongti guihua ("urban planning guidelines"), in which the essential principles to be adhered to are as follows: sparing use of land and resources, protection of the environment, high economic efficiency, and social harmony. ${ }^{(8)}$

A number of national programmes have been launched to promote pilot sustainable development cities. A first "eco-city" platform was developed by the Ministry of Housing and Urban-Rural Development (MoHURD, the key urban planning ministry in China), and a second by the Ministry of Environment Protection. ${ }^{\left({ }^{9}\right)}$ A new concept of "low-carbon cities" emerged in 2011 (with the $12^{\text {th }}$ Five-Year Plan), along with a new national programme selecting eight pilot cities and five pilot provinces. In addition to these national programmes, there has been a number of projects for new so-called "ecological" cities since 2006. The most ambitious of these (the eco-cities of Dongtan, Tianjin, Qingdao, Caofeidian, etc.) are the subject of international cooperation (with Singaporean consortiums and American and northern European companies and universities) and major communication campaigns, but the actual substance of these projects is not currently clear The environmental theme has become so prominent and so key to the urban question in China that any new urban development is now immediately given the "eco-city" stamp by the local authorities in charge of the project. By taking up Western concepts of the sustainable city and promoting them in an equally voluntary manner, the Chinese authorities have shown their ambition to promote environmental excellence at an international level.

Therefore, a number of years ago, China appeared to embrace an environmental watershed in the way in which it plans and builds cities, even inventing new ways of designing cities that demonstrate an exemplary level of consideration for the environment. What really counts, however, is the shift from words to action: has the way in which cities are planned and constructed on the ground changed to incorporate environmental principles?

\section{Research method}

This research combined bibliographical work and fieldwork, involving analysis of the Chinese pyramidal planning system and research into actual urban operations (in particular that of the Suzhou Industrial Park in Suzhou).

The bibliographical work took in research based on a considerable number of publications (academic, official reports and administrative documents, press articles, etc.) dealing with urban development and planning, as well as protection of the environment in China. In order to dissect the urban planning procedure, I made particular use of the analysis in the work Chengshi guihua yuanli(10) ("Principles of urban planning"), which is viewed by many in China as the "bible of urban planning." It is the reference manual used by all urban planning students and practitioners, basically setting out the road map for urban planning.

The fieldwork involved approximately 50 semi-directive interviews (each lasting for one-and-a-half to two hours and carried out in English or Chinese depending on the participants) conducted in Shanghai, Suzhou, and Beijing, during two field missions carried out in April-May ${ }^{(11)}$ and November-December 2012. Various types of actors were interviewed, including administrative officers within the Shanghai and Suzhou city councils responsible for urban planning and protection of the environment; managers of private companies managing urban networks; urban planning architects working in research consultancies and urban planning agencies; experts working in international institutions (OECD, French Development Agency); and researchers and professors of urban planning and environmental studies (Tongji, Tsinghua, ECNU, etc.). These interviews were supplemented by site visits and field notes, in particular in Shanghai and Suzhou.

\section{Research in the field reveals urban zoning deployed on a vast scale}

From an environmental point of view, Chinese "eco city" projects remain largely at the intention stage: some announcements made amid great pomp have not actually seen the light of day (for example, the flagship project in Dongtan designed by Arup), ${ }^{(12)}$ while others have been acted upon but contain no significantly ecological aspects (such as the new city of Anting in the Shanghai municipality), ${ }^{(13)}$ and still others remain at a very early stage of development (for example, the eco cities of Tianjin and Qingdao). A veil has now been cast over the various national programmes for "sustainable cities," and it was not possible to find a single publication that shed light on them. Similarly, the people I interviewed did not appear to have any specific information. One professor from Tongji University ${ }^{(14)}$ gave us his opinion: "Eco-cities? They are nothing but slogans! Maybe in 15 years we'll be able to talk seriously about sustainability in China." Several other professors in Tongji and Tsinghua confirmed this analysis. ${ }^{(15)}$ Recent academic publi-

6. Wu Zhiqiang et al., Chengshi guihua yuanli (Principles of city planning), Tongji University, Zhongguo Jianzhu Gongye Chubanshe, 2010 (4 $4^{\text {th }}$ edition), pp. 70-75.

7. Wu Zhiqiang et al., Chengshi guihua yuanli, op. cit., p. 72.

8. Wu Zhiqiang et al., Chengshi guihua yuanli, op. cit., p. 278.

9. See Chien Shiuh-Shen, "Chinese eco-cities: A perspective of land-speculation-oriented local entrepreneurialism," China Information, Vol. 27, 2013.

10. Wu Zhiqiang et al., Chengshi guihua yuanli, op. cit.

11. Some of the interviews in the first mission were carried out in collaboration with Dominique Lorrain.

12. See Frédéric Obringer, "Les écovilles en Chine. Du rêve nécessaire à la réalité marchande" (Ecocities in China: From necessary dream to market reality), in Mouvements, No. 60, 2009, pp. 29-36.

13. Interviews conducted with professors at Tongji University, April-May 2012 and November 2013.

14. Interview conducted on 24 April 2012.

15. Interviews conducted in December 2012 
cations $^{(16)}$ also reveal the lack of environmental substance of the urban operations referred to as "eco-cities" or presented as exemplary from an environmental perspective in China.

The fact that no substantial eco-city has yet been completed should not be a surprise in itself, given that the environmental watershed announced by the authorities and the launch of the first eco-city projects are recent events, dating back just eight years to 2006. What is of concern, however, is that the new cities currently being built around the major urban centres of the country (Shanghai, Suzhou, Tianjin, Chongqing, Wuhan, etc.) do not seem to be very different from those that were built during the 1990s and 2000s, and appear to be far removed from what might commonly be held up as the image of a "sustainable city." (17) Indeed, visitors to these new cities find themselves passing through urban sectors in which large single-function blocks (residential area, industrial zone, shopping precinct, administrative area, etc.) are set side by side on huge areas of land, embodying functionalist urban planning deployed on a vast scale.

The case of the new city of Suzhou Gongye Yuanqu, literally "Suzhou Industrial Park" or "SIP," provides a helpful illustration of this urban planning model. Created in 1994 by the Chinese central government as part of a strategic partnership with a Singaporean consortium, most of SIP was built during the 2000s (it has now reached $80 \%$ completion). Administratively, it is categorised as an urban district of the Suzhou municipality. Located to the east of the old centre of Suzhou and in close proximity to Shanghai, it has grown to cover a huge area of $288 \mathrm{~km}^{2}$, and is home to approximately 800,000 inhabitants (more than half of whom are non-permanent residents) and nearly 10,000 companies ${ }^{(18)}$ (including many multinationals). It is a flagship operation in China in terms of economic development, urban planning, and protection of the environment. Drawing on Singaporean know-how and massive investments, SIP has grown at a swift and controlled rate, and greater consideration has been shown to the environment compared to other urban-industrial operations in China, ${ }^{(19)}$ in particular as a result of systematic and integrated planning and management of the various urban activities and the technical networks of essential services. However, in terms of the choices made in the organisation of the city, SIP is typical of new Chinese cities:

- a broad orthogonal road system (50 to 60 metres wide) forming a massive grid (two sets of two lanes or three sets of three lanes, which bear a closer resemblance to motorways than to streets);

- an urban morphology featuring lines of large square blocks a few hundred metres wide that are relatively closed off, each block having only one or two entrances;

- an arrangement of urban functions split strictly into sectors. All the blocks are single-function, and there is a very clear separation of functions over the cityscape as a whole. ${ }^{(20)}$

The city covers an enormous area of $288 \mathrm{~km}^{2}$, approximately $20 \mathrm{~km}$ by $14 \mathrm{~km}$, which is nearly three times the size of the city of Paris. Everything is arranged (immense) block by (immense) block, (immense) sector by (immense) sector. When combined, the three factors described above concerning the organisation of the city make it almost impossible to travel from place to place in SIP without motorised transport. Moreover, the small number of previous inhabitants and the flat topography that characterise the location mean that it was possible to assemble this "machine" of functionalist urban planning with a minimal amount of political, social, and physical friction; the result is a hyper-functional set-up dominated by its matrix arrangement.
This urban planning model can be seen in each of China's new cities (21) including in the eco-city of Tianjin (an urban operation started in 2007 and today considered by many Chinese experts I interviewed in the country to be the most ambitious project yet in environmental terms) and recent "low carbon city" operations: "Compactness, density, functional mix, connectivity, and promotion of soft transport modes are notions missing from most existing 'low carbon city' projects. China has a long way to go before it masters the concepts and practices of sustainable urban development," state experts from the French Development Agency. ${ }^{(22)}$ Therefore, the $288 \mathrm{~km}^{2}$ SIP is not the only city designed as a hyper-functionalist machine; the same model is deployed in other massive spaces in China.

The aim of this article is to try to understand the major discrepancy between the concepts of sustainable urban development proclaimed by the authorities and the reality on the ground by lifting the lid on the black box of the political and administrative system of Chinese urban planning in order to shed light on urban planning procedures currently being implemented in China, the mechanics of drawing up and producing this urban machine, the overall architecture, and the workings and the metrics behind its construction process, by examining the various steps of the process (from the centrally-defined planning principles to the material construction of each urban block) and by considering all the component parts of urban planning (housing, industrial, commercial and administrative activities, and infrastructure networks - roads, water supplies, waste-water and rain-water management, electricity, gas and heating supplies, waste management, etc.). What guiding objectives, reasoning, principles, rules, tools, and operating standards lead to the production of new Chinese cities in the form they currently take, from the macro scale, nationally, through the planning of a new city, down to the construction of a single block? This analysis makes it possible to examine the extent to which environmental principles have or have not been incorporated into this urban planning procedure.

This study also explores a research question of more general significance that also concerns other developing countries, and which is keenly illustrated by the Chinese context: that of how to reconcile increasing concern for the environment within the population and now officially shouldered by the authorities, and the pursuit of development and urbanisation on a massive scale, which requires colossal quantities of equipment and infra-

16. C. P. Pow and Harvey Neo, "Seeing Red Over Green: Contesting Urban Sustainabilities in China," Urban Studies, Vol. 50, 2013; Chien Shiuh-Shen, "Chinese eco-cities: A perspective of land-speculation-oriented local entrepreneurialism," art. cit.

17. At present, the concept of a "sustainable city" is more a goal that public authorities in developed countries and some emerging countries are aiming to achieve than a clearly defined and well established object, and the model "eco-city" has yet to be built. Nevertheless, certain countries and cities, in particular in northern Europe, have gone a long way in incorporating new city planning principles to promote greater protection of the environment since the 1990s, for example compactness, a functional mix, promotion of non-polluting transport, etc

18. Information gathered during interviews with administrative officers in SIP (April-May 2012).

19. Indeed, within China, SIP is universally considered to set the environmental benchmark owing to the quality of the infrastructure and environmental services, landscaping, and environmental control of industrial activities, as well as the experiments in industrial and urban symbiosis (networks for reusing energy resources between different activities, whether industrial or residential) carried out there. See Rémi Curien and Dominique Lorrain, "Towards sustainable cities in China? Two industrial parks in the Yangzi delta," International seminar: "From networked to post-networked urbanism: New infrastructure configurations and urban transitions," École des Ponts ParisTech and Université Paris Est, Autun, July 2012, 24 pages, www.enpc.fr/sites/default/files/green_citiescurien-lorrain-oct2012.pdf (accessed on 18 May 2014).

20. Observations made in the field in April-May 2012.

21. As far as the municipalities of Shanghai and Suzhou in the Yangtze Delta are concerned: SND (Suzhou New District), Kunshan, Changshu, Jinshan, Lingang, etc.

22. Jin Xiaoting et al., "Les villes chinoises, laboratoires de la sobriété énergétique?" (Chinese cities: A testing ground for energy-saving?", Urbanisme, No. 325, 2010. 


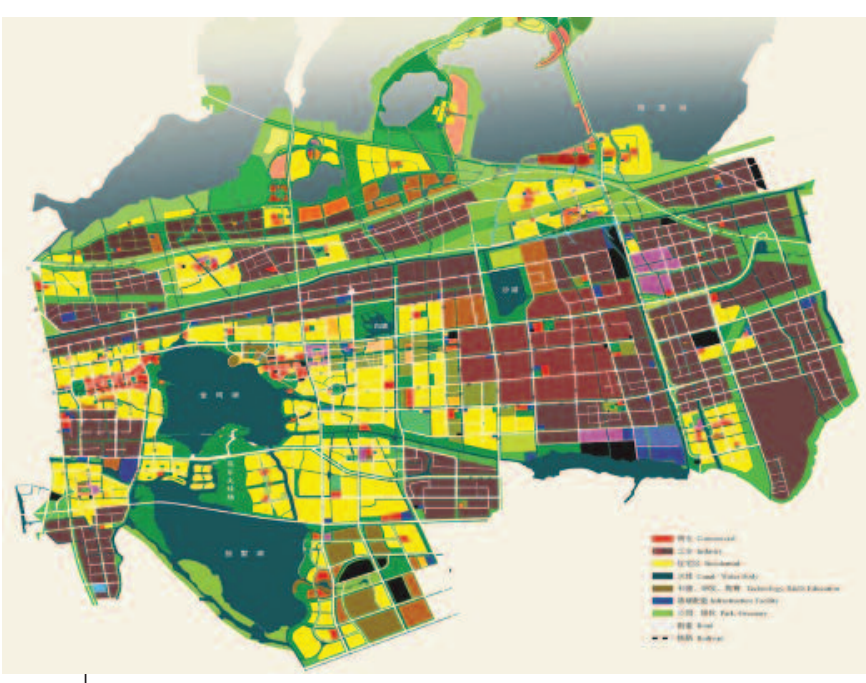

Map 1 - Urban planning map of the Suzhou Industrial Park in 2012.

(c) SIP Administration Committee

structure in order to accommodate between 15 and 20 million new city dwellers annually. How can room be found for the necessity of environmental quality in urban planning when the structure of the operating context is hyper-productivist and functionalist? How can a train travelling at highspeed along a straight track be made to change direction?

\section{The Chinese urban planning procedure}

This study will first examine the planning procedure before analysing the political and economic reasoning that underpins it. Two main characteristics explain the urban model deployed over the country as a whole: the strict pyramid structure of the Chinese planning system, and the hyper-functionalist approach of the urban planning protocol.

\section{A strict pyramid system}

The Chinese political and administrative system is, as a whole, organised into a strict vertical pyramid structure: the basic points originate in Beijing and are then deployed across the territory, which is split into the different interlinked administrative territorial levels (state; provinces, autonomous municipalities, special administrative regions or autonomous regions; municipalities or counties; towns or villages). ${ }^{(23)}$

The first key element is the allocation of ground to be urbanised. This is the fundamental piece of data in the Chinese urban planning system. An "overall land use plan" (tudi liyong zongti guihua) - which adheres to the principles of the "Land use law" (tudi guanli fa) (24) of the PRC - is defined centrally by the Ministry of Land Resources. ${ }^{(25)}$ Province by province, this national plan designates the maximum area of ground that can be urbanised. Next, each province defines a land use plan that sets the maximum amount of land that can be urbanised, municipality by municipality, and so on down through the levels to the town level. (26) For example, the municipality of Shanghai was not authorised to urbanise more than $100 \mathrm{~km}^{2}$ of land over the course of 2012, while Hangzhou was restricted to $50 \mathrm{~km}^{2}$ and Ningbo to $30 \mathrm{~km}^{2}$. (27) This system of allocating land for urbanisation is strictly controlled by the Ministry of Land Resources.

Secondly, the administrative and legal system of urban planning is also organised into a pyramid structure. It is based upon a set of specific laws, rules, and standards defined centrally and spread over the country as a whole. (28) The urban planning guidelines and plans are part of an interlinked administrative urban planning system.

The fundamental law is the "Urban and rural planning law" (chengxiang guihua $\mathrm{fa}$ ), which is itself determined by a law concerning the planning of the economic and social development of the country. Drawn up by the MoHURD and voted by the National People's Congress of China, it defines the broad principles to follow across the country as a whole. The law was last revised in 2008, the aim being to introduce more sustainable planning. (29) Technical rules and guides specify the methods and standards to be applied nationally, generally, or by sector: "Procedure for drawing up urban planning" (chengshi guihua bianzhi banfa), "Standards for planning and constructing residential zones" (chengshi juzhuqu guihua sheji guifan), "Standards for planning and constructing roads" (chengshi daolu jiaotong guihua sheji guifan), "Standards for planning and constructing water distribution systems" (geishui guihua sheji guifan), and so on for electricity, gas, wastewater, waste, etc. Next come the local technical regulations, which adjust the national standards in order to give greater consideration to the local context. These rules and standards are revised on a regular basis, but everyone we interviewed indicated that they had basically not changed since the 1990s.

Dealing in more specific terms with urban planning documents and guidelines, three different levels can be identified, ranging from the abstract to the concrete and from the strategic to the operational: the quyu guihua ("regional plan") at the provincial level, the zongti guihua ("overall plan") and the xiangxi guihua ("detailed plan") at the municipality or urban district level. The purpose of the regional plan (quyu guihua) is to guide and organise urban development at a regional level (economic centre, system of cities, main industrial zones, main infrastructures, etc.). However, the two urban planning documents that govern the planning and construction of a new city are the overall plan (zongti guihua) and the detailed plan (xiangxi guihua). The overall plan (zongti guihua) is a set of long-term strategic guidelines, in theory designed to take a 20 -year period into account. It sets the objectives, targets, and scales (economic, demographic, and spatial) for urban development, and the principles of spatial organisation for urban development in the planned area. ${ }^{\left({ }^{0}\right)}$ The detailed plan (xiangxi guihua) is a specific plan for a city, and has an operational outlook that defines, for each block of the area in question, the use, density, height, and volume of buildings, the proportion of green spaces, and the proportioning of public and essential services (water, energy). ${ }^{(31)}$ These various levels of urban planning are interlinked, and the detailed plan (xiangxi guihua) must follow the principles defined by the overall plan (zongti guihua), which itself must comply with those defined by the regional plan (quyu guihua) that governs it. Each administrative level is responsible for drawing up, applying, and controlling

23. Interviews with professors from Tongji, April-May 2012.

24. This law imposes a red line forming an area of 1,800 billion $\mathrm{m}^{2}$ (which represents one-ninth of the total surface area of the country) around land protected for agricultural use (interview with a professor from Tongji, 24 April 2012)

25. Wu Zhiqiang et al., Chengshi guihua yuanli, op. cit., p. 209.

26. The system for allocating land to be urbanised is therefore very much organised into a pyramid structure. However, there can be a margin for negotiation between two neighbouring administrative levels, meaning that the lower level can claim more land to urbanise from a higher level.

27. Interview with a professor from Tongji, 10 December 2012.

28. Wu Zhiqiang et al., Chengshi guihua yuanli, op. cit., pp. 52-60.

29. Idem., pp. 50-65.

30. Idem., p. 174.

31. Idem., p. 300. 


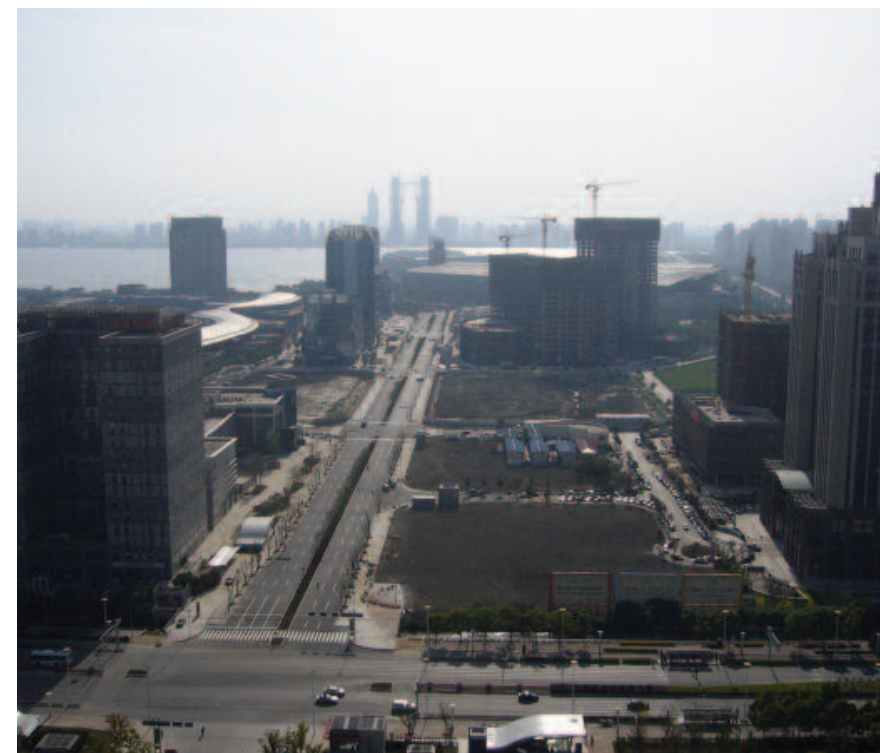

Photo 1 - Birdview of the Suzhou Industrial Park in 2012. () Rémi Curien

its urban planning documents. However, these also need to be approved by the next adminsitrative level up in order to enter into force. For example, the overall plan (zongti guihua) of a municipality must be approved by the provincial government. Finally, the Urban and Rural planning law stipulates that urban planning plans developed by a territorial level must be modified when the administrative government one level higher introduces a planning change, or when the State Council ratifies a revision of the planning principles. ${ }^{(32)}$

Therefore, from the system of allocating land to be urbanised to the system of drawing up, approving, and modifying territorial planning documents, not to mention the corpus of urban planning laws and standards, the entire architecture of urban planning in China is interlinked and organised into a strict pyramid structure. The next aspect to examine is the procedure for planning a new Chinese city.

\section{Planning a new city: A hyper-functionalist protocol}

This aspect of the question is best explored from the municipality or urban county level, at which the concrete planning of new cities takes place through the overall plans (zongti guihua) and the detailed plans (xiangx guihua). This organisation of the urban planning protocol is based upon corroborating information gathered from my interview campaigns, and on analysis of the Chengshi guihua yuanli.

The first step involves deciding on the population growth to be incorporated into the land earmarked for urbanisation. This demographic forecast determines the whole subsequent planning process. In Suzhou, for example, the head of the construction and urban planning bureau of the municipality ${ }^{(33)}$ told me that:

The urban planning bureau of the municipal government controls all the planning of the different areas of Suzhou. We have an urban planning system to determine the distribution of the population between SIP, SND, Kunshan, and Wujiang [different urban districts of Suzhou]... The municipality of Suzhou is thus forecasting the number of people and the main infrastructure (such as drinking water treatment sta- tions and high capacity electricity power plants) it needs to put in place on its territory.

Based on this demographic growth forecast, planners set the number of square metres of land that needs to be urbanised. A simple mathematical formula is used to define this quantity; ${ }^{\left({ }^{34}\right)}$ this $(A)$ is the product of the quantity of population $(P)$ multiplied by a coefficient of land use per inhabitant (a): A = P. a

This means that China has a set standard for urban land use per inhabitant, determined by the national document "Standards for urban use and construction" (Chengshi jianshe yongdi fenlei yu guihua jianshe yongdi biaozhun), (35) which plays a key role in urban planning. This figure is approximately $100 \mathrm{~m}^{2}$ per person, though it can vary from 60 to $120 \mathrm{~m}^{2}$ per person depending on the size and characteristics of the city.

Once the number of square metres of land to be urbanised has been defined, the proportions allocated to the various urban functions need to be set. These proportions are broadly fixed at the national level, and can be adjusted locally. ${ }^{(36)}$ They are therefore fundamentally identical from one new city to the next. The types of uses of land, established by the MOHURD in 1990, have changed little since then (the impact of the most recent revision, which took place in 2008 in order to comply with the new Urban and Rural Planning Law, was minimal), and include a residential function, an industrial function, a shopping function, a cultural and educational function, an administrative function, a public and essential service facilities and infrastructures function, a storage function, a green spaces function, etc. For example, in SIP, the industrial function currently covers $30 \%{ }^{\left({ }^{(3)}\right)}$ of the space, while $20 \%$ is given over to the residential function, with the rest of the space being shared by the remaining functions.

Once decisions have been made with regard to the urban functions, they are arranged in space according to a large-scale zoning (quhua) approach, in which each block is allocated a single function: there are therefore residential zones, industrial zones, shopping zones, cultural and educational zones, administrative zones, green space zones, and so on. Functional zoning is stated to be a major urban planning principle: "Each block has a defined function" (mei kuaidi dou you yiding de yongtu). (38) The residential, shopping, and cultural and educational zones are generally arranged close to each other, whereas the industrial zones are further away owing to the pollution that they generate.

These first four steps are guided by the overall plan (zongti guihua), while the subsequent actions are covered by the detailed plan (xiangxi guihua).

Next, the layout of the construction is defined for each block. For a residential block, this means setting the quantity of homes and the density and volume of construction. Similarly, for an industrial block, the quantity of buildings and the construction volumes are determined. ${ }^{(39)}$

This is the basis upon which the essential service networks (water, electricity, gas, and wastewater) are proportioned, block by block, with different

32. Idem., p. 178.

33. Interview conducted on 12 December 2012.

34. Wu Zhiqiang et al., Chengshi guihua yuanli, op. cit., pp. 269-270.

35. Idem., p. 270. Document published by the Ministry of Construction.

36. Idem., p. 215; this point was confirmed by my interview with the head of the city planning bureau of SIP, 18 December 2012.

37. This proportion in SIP is slightly higher than that of a standard new city, because SIP has a more pronounced industrial bearing. For example, the proportion in Shanghai is $26 \%$ (interview with a professor from Tongji, 24 April 2012).

38. Wu Zhiqiang et al., Chengshi guihua yuanli, op. cit., p. 185

39. Idem., p. 308. 
standards applied depending on the urban function. As pointed out above, residential zones on the one hand, and industrial zones on the other, are each grouped together, generally forming two very separate and quite distinct urban sectors. This use of large-scale zoning for the purpose of urban planning has major implications when it comes to the design and management of essential service networks. The standards, systems, and networks for water ${ }^{(40)}$ and energy distribution, and for wastewater disposal, differ depending upon the zone (residential or industrial) that they serve.

The construction of new Chinese cities therefore proceeds according to a hyper-quantitative, matrix-based functionalist method, reflected as a pyramid structure from the plan allocating land to be urbanised, which is drawn up in Beijing, to the proportioning of every urban block in each new city, and is embodied by urban zoning on a vast scale. Everything revolves around detailed standards and urban functions, leaving little room for qualitative considerations, discussions airing other points of view as to how to lay out cities, and dialogue with local stakeholders, in particular populations. This quantitative outlook upon which urban planning is based in China is also emphasised by researchers I interviewed:

Urban planning is a highly technical discipline in China. The work of the Chinese urban planner consists of dealing with technical questions. The rest (such as the implications of choices made in urban planning with regard to energy consumption or social integration) does not concern him. ${ }^{(41)}$

Urban planning in China belongs purely to the realm of the hard sciences (gongke), which completely overlooks social dimensions or the concerns of the population. ${ }^{(42)}$

This model of large-scale zoning for the purpose of urban planning is generally presented as the obvious choice by most urban planning practitioners we interviewed, and by the Chengshi guihua yuanli, which offers no scientific evidence of its validity. The following terms are most commonly used to justify zoning: heli (rational, logical) and qingxi (straightforward, clear-cut). Zoning appears to be the most rational model (the term xiaolü - efficient - also crops up often) when it comes to constructing a new city:

We think that this model [zoning] is a very good and very rational (heli 合理) model, because there are major differences in the way water is used in residential areas and industrial areas. (Manager of Towngas, a company managing the water and gas distribution networks in SIP, translated from Chinese) ${ }^{(43)}$

Another virtue attributed to zoning is the clarity that it offers: "Functional zoning (gongneng xing fenqu 功能性分区) guarantees a straightforward (qingxi 清晰) overall structure of the various urban activities" (44) (translated from Chinese). The former head planner of SIP(45) even points to the clarity of zoning in SIP, which he claims is greater than that of the other new Chinese cities:

Our industrial park is comparatively [as against other new cities or development zones] more concentrated (jizhong 集中), the residential areas are more concentrated, and we have provided an even clearer separation of the functions. It is something of an urban zoning model in terms of clarity (chengshi fenqu de moshi 城市分区的模式). (Translated from Chinese)
In addition to the clarity of the zoning, ideas such as order (youxu) and security (anquan), which are notions of key importance in China, are often used by urban planners.

Most of all, this zoning model makes it possible to make considerable savings in costs related to urban planning and construction, ${ }^{(46)}$ to construct large cities very quickly, and therefore to urbanise the country in an accelerated manner.

The interviews conducted confirm that there has been little change in urban planning and construction procedures used in China, and that the integration of environmental principles remains unsubstantial. Chinese academic experts generally swing between constructive criticism and fatalistic pessimism. A professor at Tsinghua refers to "letters of good intentions," another confirms that there has been "no major change," and a professor at Tongji spoke of a "major discrepancy between stated aims and actual practice in reality." (47)

When we spoke to urban planning practitioners responsible for urban operations in Shanghai and Suzhou about the way in which they take the environmental dimension into consideration in their urban planning work today, their answers reveal just how little bearing, if any, environmental questions have on decisions concerning choices in urban organisation (urban forms, the arrangement of urban functions, the design of technical networks for essential services). The process of planning new cities does not involve any overall and systemic consideration for environmental matters. The specific points made in the answers we gathered were generally as follows:

- "greening" (lühua), i.e., guaranteeing that large areas of ground will be planted with vegetation;

- the energy efficiency of the buildings (even though this is not directly a component of urban planning);

- the environmental assessment of each industrial activity (same observation as above);

- development of the public transportation offer (however, car ownership and use are still rapidly increasing).

Even the official reference manual, Chengshi guihua yuanli, subtly emphasises in several places the discrepancy between the law and the goals that have been set on the one hand, and real-world practice on the other hand. It points to the necessary development of methods of using land earmarked for urban construction, with the increase in the importance of environmental concerns (p. 182). The "points to which the overall plan (zongti guihua) for cities needs to give greater priority" (in other words, the points that are not currently given sufficient consideration in China) include "protecting

40. "In cities, different forms of water distribution can be adopted depending on whether the zone is industrial or residential" (Wu Zhiqiang et al., Chengshi guihua yuanli, op. cit., p. 445).

41. Interviews with a city planning professor from Tongji, 20 April 2012.

42. Interview with a sociology professor from ECNU, 7 May 2012

43. Interview on 11 December 2012.

44. Wu Zhiqiang et al., Chengshi guihua yuanli, op. cit., p. 286.

45. Interview on 13 December 2012.

46. The high speed of construction does not come without its own major problems in terms of quality and durability. The rate of ageing of infrastructure built in recent years in China is especially high, and a large portion of it will probably need to be rebuilt in the medium term (interview with one of the experts from the French Development Agency and the OECD in Beijing, 29 November 2012).

47. Interviews held respectively on 30 November 2012, 29 November 2012, and 20 April 2012. 
natural and cultural resources" (48) and "improving the management of public infrastructure and services" (in particular the management of water, wastewater, and waste) (p. 296).

This hyper-functionalist urban planning model has not yet been called into question by Chinese decision-makers. A professor from Tongji (49) believes:

We may have academic debates [concerning urban planning models], but unfortunately urban planning continues to be physical-planning oriented in today's China.

Nevertheless, there are signs of a potential change. In academic and professional circles concerned with urban planning, large-scale zoning is attracting an increasing amount of criticism. Urban planning architecture firms and consultancy businesses in China and internationally are proposing increasingly mixed and sober urban models. ${ }^{(50)}$ Although these new ideas are gaining ground among urban planning researchers and practitioners in China, they are not yet gaining traction on the ground, because political decision-makers - who hold all the power in this area - have no intention of challenging the existing urban planning and development procedure.

In order to help explain this functionalist pyramid model of planning in China, it is helpful to examine the main cultural and political principles that hold sway and the economic and institutional reasoning that underpins them.

\section{The basic principles of the Chinese urban planning procedure}

\section{Soviet influence and the modernist model}

The Chinese planning procedure draws inspiration from Confucianism in terms of order and hierarchy, but has, above all, been shaped by reference to the Soviet example ${ }^{(51)}$ (evoked in the 1950s to organise the reconstruction of the country and plan its industrialisation) and by its directed and planned economic development and urban planning model. The omnipotence of a single party, a top-down development process, the primacy of the physical approach and technical rationality (urban planning seen as a tool for bringing national economic planning to fruition), and a two-tier system (the overall urban planning plans and detailed construction plans) are all features borrowed from the Soviet model that have become rooted in the Chinese system of urban planning. (52)

Since the 1980s, Soviet influence has been combined with the pursuit of a modernist urban planning model involving large-scale zoning. The Athens Charter (Yadian xianzhang) has occupied a prestigious position in the teaching of urban planning since the 1980s in China, and continues to do so. ${ }^{(53)}$ Many experts consider this to represent Chinese urban planners' fascination with the American model of an urban grid deployed on a vast scale (the Chengshi guihua yuanli dedicates a major section to Frank Lloyd Wright's Broadacre City), which they consider to be one of the benchmarks of modernity and success. The grid shape also has Chinese roots (traditional grid plans). ${ }^{(54)}$

To this day, the urban planning system and procedure continue to be deeply structured by the Soviet model. However, what has changed significantly since the 1980s and the economic reforms of the opening up of China are the scale of urban development and the financing of urban planning, which are now driven by the market. ${ }^{(55)} A$ Chinese expression coined by a professor from Tongji (56) neatly sums up this new order: "The govern- ment constructs the scene, the market plays the opera (zhengfu datai shichang changxi). The government sets the rules of the urban planning game and supervises its progress, but the main operational players (in terms of the construction and management of facilities and infrastructures) are now companies (property developers, construction companies, essential service companies, etc.). The inherited model of directed functionalist planning defines the principles of urban planning and the zoning matrix, forming the framework of the urban machine. The massive demands made on the market and foreign capital to finance urban development extends the scale and speed at which the matrix is deployed.

\section{The priority objective of maximising economic growth}

The key that explains this hyper-functionalist urban machine is the absolute priority given to accelerated growth set by the central Chinese government in the 1980s, involving maximising the growth in Gross Domestic Product (GDP) at all of the territorial levels in the country. Any concern of an environmental or social nature is marginalised. The whole of the current political and administrative system in China has been shaped with this aim in mind.

The first factor is the decentralisation of political power in terms of urban development and planning, which took place in the 1980s. ${ }^{(57)}$ Local political leaders are appointed by their hierarchical superiors in the Communist party-state, and progress in the organisational chart of the CCP depending on the assessment made by the central party-state. Therefore, any action by local authorities and planners depends on the requirements of the partystate hierarchy, not the concerns of the local populations, ${ }^{(58)}$ unlike the situation in Europe, where local power tends to focus on its relationship with its citizens rather than with the central government, and where local urban identities are therefore more pronounced. ${ }^{(59)}$ This powerful central control is also a major factor when it comes to explaining the uniform nature of the new Chinese cities. The second factor is the way power is concentrated at each territorial level in the hands of the local first secretary of the Party. The third factor, and one that should not be underestimated, is the system

48. Moreover, it is interesting to note that natural resources and cultural and historical heritage are often combined and categorised in the same category in lists describing the various urban sectors by subject: "protecting nature, cultural and historical heritage, and other elements of this type" (ziran he lishi wenhua yichan deng fangmian de baohu) (p. 175); and therefore renwen yu ziran ziyuan baohu (p. 296). Natural resources and cultural heritage may not be obvious bedfellows in principle, and the main feature they share is that they are all "to be protected," since they are seriously damaged by high-speed development.

49. Interview conducted on 10 December 2012.

50. Interviews with Chinese and foreign architects and city planners in Shanghai, May 2012.

51. "Our territorial planning system in China is imported from the Soviet model," (former head planner of SIP, interview conducted on 12 December 2012 - translated from Chinese).

52. In particular see: Anthony Yeh and Wu Fulong, "The transformation of the urban planning system in China from a centrally-planned to transitional economy," Progress in Planning, Vol. 51, 1999, pp. 167-252.

53. Wu Zhiqiang et al., Chengshi guihua yuanli, op. cit., pp. 31-33.

54. Interview with a professor from Tsinghua, 30 November 2012.

55. The case of Suzhou provides an apt illustration of this. See Rémi Curien, "The growth of development zones and the urban planning strategies in Suzhou," 13 March 2013, http://urbachina.hypotheses.org/3401 (accessed on 18 May 2014).

56. Interview conducted on 4 December 2012.

57. In particular see Zhang Tingwei, "Planning Theory and Reform in Transitional China," City Planning Review, Vol. 32, 2008, pp. 15-24.

58. Interview with a sociology professor at ECNU, 7 May 2012.

59. In particular see Patrick Le Galès, Le retour des villes européennes (The return of European cities), Paris, Presses de Sciences Po, 2011 (2nd edition). 
by which political functionaries are assessed. They are assessed every five years, essentially on the criterion of growth in GDP in the territory they govern (environmental criteria, for example, are still very marginal). ${ }^{(60)}$ In addition to the above, a fourth factor is the term of office. Each local leader is required to change administrative territories every five years, which means political and economic horizons are narrow, resulting in intense competition between the political officers of different territories. They are therefore mainly assessed on the basis of the level of economic growth of the territory they have administered over the preceding five years, the main indicators of this growth essentially being urbanisation and land rent (concession of land to the private sector for use in emphyteutic leases). The officials who make the fastest progress in the organisational chart of the Chinese partystate are therefore those who develop their territory the fastest. ${ }^{(61)}$ Moreover, because all power is concentrated in the hands of a single party, this accelerated development is not limited by other forces (political, media, or social), except in certain cases when popular action succeeds in preventing the construction of waste or wastewater processing plants in the immediate proximity of peoples' homes.

These factors help explain the benefits of a functionalist pyramid method of planning and the physical choice of large-scale urban zoning, for they appear to provide the most effective means of constructing large cities very quickly, of carrying out urbanisation on the largest scale and as quickly as possible, and in so doing achieving the ultimate political goal of maximising economic growth.

This urban entrepreneurialism has brought with it increasingly acute problems in terms of territorial coherence and environmental balance at a regional level. Indeed, the institutional system automatically brings with it an exacerbated level of competition between territories in the race to develop. In Suzhou, for example, there is massive competition between the various districts of the municipality (SND, SIP, Kunshan, Wujiang, and Zhangjiagang). This competition also exists between Suzhou and the other municipalities within Jiangsu Province (Nanjing, Wuxi, Changzhou, Zhenjiang, Yangzhou, Taizhou, and Nantong), as well as with the municipality of Shanghai. ${ }^{(62)}$ Also, at the level of every new city, the result of this hyper-competitive institutional set-up is that the local specificities of territories are reduced to a minimum, development and planning is accelerated and beset by short-termism, and urban planning and construction timelines are compressed to the extreme. The growing phenomenon of "ghost cities" (63) (sicheng, "dead cities" in Chinese) - cities that have been built but have no inhabitants - illustrates this problem of spatio-temporal coordination in terms of urban supply and demand.

\section{An increasing discrepancy between urban planning and construction}

Moreover, the Chinese urban machine, which is often portrayed as being ordered and controlled, is not as closely managed as might be imagined. Although the planning procedure analysed above does indeed define the broad principles of new cities in terms of proportioning and organisation, it seems that an increasingly wide gap then develops between aspects that are established in urban planning documents and the actual contruction of the various zones, blocks, and networks on the ground. (64) China has serious problems in terms of applying urban planning plans and controlling construction. The content of my interview with the head of the construction and urban planning bureau of Suzhou municipality ${ }^{(65)}$ supports this obser- vation and expresses the instability of urban planning and the general powerlessness of urban planners when they come up against all-powerful political power:

In Chinese, we have an expression: "planning? A plan drawn on a piece of paper is worth less than a sentence from the boss" (guihua guihua, zhishang huahua, bu ru lingdao yi ju hua). This means that in China, planning is enormously dependent on the goodwill of the local Party leader; even if we take many things into consideration in the drawing-up and planning process, at the end of the day it depends on the leader's will, so the wishes of one man can result in many changes. We also say "one leader = one plan" (yi ren shuji, yi ren guihua), because in China the terms of office of city leaders are very short. They generally have to change every three or five years, so such-and-such leader produces one plan, and the next will probably undo everything. ${ }^{(66)}$ (Translated from Chinese)

\section{Conclusion}

This research shows that the construction of new Chinese cities starts with a generic, hyper-quantitative, and productivist planning method, reflected as a pyramid structure over the whole country, and is embodied by the accelerated construction of a hyper-functionalist urban machine. This procedure was chosen by the Chinese authorities in order to carry out the largest-scale, fastest, and most ordered urbanisation possible, and to thereby achieve the ultimate goal of maximising economic growth. It has changed very little since it was decided upon in the 1980s, and to this day is not significantly called into question in China.

There are few signs of environmental principles being taken significantly on board in the way cities are currently produced in China. Concepts and aims of sustainable urban development are drawn up, but there are no operational tools for incorporating these principles into the procedure of urban planning and production. The vague nature of the environmental criteria contrasts with the accuracy of the quantitative standards of zoning. Conversely, all the political reasoning that currently dominates urban develop-

60. A large number of my interviews, both with academics and with actors involved in city planning operations, converge on these two points.

61. Owing to the rapid dwindling of arable land as a result of this rampant urbanisation, the central government is now paying closer attention to the way in which land is made available for urbanisation (Interviews with professors from Tsinghua and ECNU, December 2012). See also issue 2013/3 of China Perspectives dedicated to the urbanisation of rural China.

62. Furthermore, moves towards forming "groups of municipalities" have recently been set in motion by the Chinese central government to better coordinate regional development (interview with a researcher from ECNU, 7 December 2012).

63. Many experts I interviewed in various cities (in Shanghai, Suzhou, and Beijing) and institutions (universities, international organisations, private firms) during my fieldwork use this term and emphasise the importance of the phenomenon. Two recent press articles also support this observation: "Chine: les villes fantômes défient les plans du pouvoir" (China: ghost cities challenge the plans of those in power), Le Figaro, 19 August 2013, www.lefigaro.fr/international/2013/08/19/ 01003-20130819ARTFIG00175-chine-les-villes-fantomes-defient-les-plans-du-pouvoir.php (accessed on 18 May 2014); "China's Ghost Cities... Are Multiplying," Zero Hedge, 21 September 2013, www.zerohedge.com/news/2013-09-21/chinas-ghost-cities-are-multiplying (accessed on 18 May 2014).

64. In particular see:Wu Fulong, "Re-orientation of the city plan: Strategic planning and design competition in China," Geoforum 38, 2007, pp. 379-392.

65. Interview conducted on 12 December 2012.

66. In this respect, the case of SIP is an exception in China. The initial plan was properly implemented because of the strict legal framework for cooperation established between the Chinese and Singaporean parties, and the pressure exerted by the Singaporean party to ensure the initial plan was adhered to. This stability and consistency of planning largely explain the status enjoyed by SIP as a benchmark in China. 
ment is devoted to a massive scale and short-termism, and is far removed from concerns of environmental quality or sobriety. China is continuing down the road of accelerated development behind the wheel of a growing, hyperfunctionalist urban machine. In order to significantly incorporate the necessity of environmental quality into the development and planning of Chinese cities, this urban machine would need to undergo a full-scale transformation:

- changing the gears of the machine: transforming every aspect of the urban planning procedure, modifying the standards, revising the hyperquantitative and functionalist method currently in force, and robustly introducing qualitative dimensions;

- changing the keys or the steering wheel of the machine: opting for a more balanced and environment-conscious model for economic growth, embedding environmental requirements much more deeply into the system of assessing and promoting officers.

Central government plays a key role, because we have seen that the system of urban planning and, more generally, the entire Chinese political system, is authoritarian and pyramidal in structure: the basic points come from the top of the Communist Party-State. China's environmental future depends on Beijing.

However, a second parameter could play a defining role in coming years: that of increasing popular pressure, which could force the Chinese authorities to make profound changes to the existing urban machine. At present there are two main aspects to this popular pressure. On the one hand, there have been increasing moves by rural inhabitants and floating populations in cities (mingong) to defend their rights to social security, which could force the authorities to start a revision of land ownership and a reform of the hukou (the system concerned with civil status and the recording of individuals, which determines one's access to social security; at present, mingong cannot obtain hukou in the city and therefore do not have the same social rights as city residents who do hold this status), and could potentially have major impacts on the speed of urbanisation, as well as on the urban planning procedure, insofar as the existing municipal finance model is based largely on savings made by denying mingong access to social security and to urban services. On the other hand, the Chinese population is becoming increasingly concerned with environmental problems generated by this development model, and in particular with air pollution and water quality, which directly affect people's health. Increasing pressure is being placed on the authorities, in particular through Internet-based social networks. Every day, millions of Chinese people write and post messages on Weibo (the Chinese version of Twitter) to expose the critical levels of pollution in the cities and demand tangible improvement. Until now, the measures adopted in response by Chinese leaders are merely papering over the cracks, and pollution levels are therefore as high as ever, if not worse. Pressure from the population is on the increase, and this level of popular mobilisation could ultimately force the Chinese authorities to implement deeper changes to the development model.

\section{Translated by Will Thornely.}

I Rémi Curien is a PhD candidate at LATTS (Laboratoire Techniques, Territoires, Sociétés [Techniques, Territories and Societies Laboratory]) at the École des Ponts Paris Tech - Université Paris Est, and a research engineer at Suez Environnement.

Laboratoire Techniques, Territoires et Sociétés, 14/20, boulevard Newton - Cité Descartes, 77447 Marne-la-Vallée (remi.curien@enpc.fr). 